\title{
Growth of Chrysanthemum in a Pine Tree Substrate Requires Additional Fertilizer
}

\author{
Robert D. Wright ${ }^{1,2,5}$, Brian E. Jackson ${ }^{1,3}$, Jake F. Browder ${ }^{1,4}$, \\ and Joyce G. Latimer ${ }^{1,2}$
}

AdDitional INDEX wORDs. container media, greenhouse crops, loblolly pine, Pinus taeda, peat-lite

Summary. A pine tree substrate (PTS), produced by grinding loblolly pine trees (Pinus taeda), offers potential as a viable container substrate for greenhouse crops, but a better understanding of the fertilizer requirements for plant growth in PTS is needed. The purpose of this research was to determine the comparative fertilizer requirements for chrysanthemum (Chrysanthemum $\times$ grandiflora 'Baton Rouge') grown in PTS or a commercial peat-lite (PL) substrate. The PTS was prepared by grinding coarse $(1$-inch $\times 1$-inch $\times 0.5$-inch $)$ pine chips from debarked loblolly pine logs in a hammer mill fitted with 3/16-inch screen. The PL substrate composed of $45 \%$ peat, $15 \%$ perlite, $15 \%$ vermiculite, and $25 \%$ bark was used for comparative purposes. Rooted chrysanthemum cuttings were potted in each of the substrates on 15 Oct. 2005 and 12 Apr. 2006 and were glasshouse grown. Plants were fertilized with varying rates of a $20 \mathrm{~N}-4.4 \mathrm{P}-16.6 \mathrm{~K}$-soluble fertilizer ranging from 50 to $400 \mathrm{mg} \cdot \mathrm{L}^{-1}$ nitrogen $(\mathrm{N})$ with each irrigation. Plant dry weights and extractable substrate nutrient levels were determined. In 2005 and 2006, it required about $100 \mathrm{mg} \cdot \mathrm{L}^{-1} \mathrm{~N}$ more fertilizer for PTS compared to PL to obtain comparable growth. At any particular fertilizer level, substrate electrical conductivity and nutrient levels were higher for PL compared to PTS accounting for the higher fertilizer requirements for PTS. Possible reasons for the lower substrate nutrients levels with PTS are increased nutrient leaching in PTS due to PTS being more porous and having a lower cation exchange capacity than PL, and increased microbial immobilization of $\mathrm{N}$ in PTS compared to PL. This research demonstrates that PTS can be used to grow a traditional greenhouse crop if attention is given to fertilizer requirements.

$\mathrm{P}$ eatmoss has provided the primary base for most greenhouse substrates over the last 30 years. Because most peatmoss used in the United States is mined and shipped from Canada, increasing energy costs are driving up the cost of peatmoss. Many studies have investigated the use of numerous industrial and agriculture wastes such as coconut coir dust (Evans et al., 1996), rubber amended substrates (Evans and Harkess, 1997), composted cotton burrs (Wang and Blessington, 1990), and earthworm castings (Hidalgo and Harkess, 2002) as substitutes for peatmoss. There have also been studies to document that sawdust can be used as a container

The research reported herein was partially funded by the Virginia Agricultural Council and by the Virginia Nursery and Landscape Association.

${ }^{1}$ Department of Horticulture, Virginia Polytechnic Institute and State University, Blacksburg, VA 24061.

${ }^{2}$ Professor.

${ }^{3}$ Graduate Teaching Assistant.

${ }^{4}$ Research Associate

${ }^{5}$ Corresponding author. E-mail: wrightr@vt.edu. substrate for greenhouse plants (Maas and Adamson, 1982; Scott and Bearce, 1972; Worrall, 1981). A more recent alternative substrate similar to sawdust was described by Wright and Browder (2005). They demonstrated that Japanese holly (Ilex crenata 'Chesapeake'), azalea (Rhododendron obtusum 'Karen'), and marigold (Tagetes erecta 'Inca Gold') could be grown in pine tree substrate (PTS) produced by grinding loblolly pine logs compared with pine bark. There were no toxic nutrient levels associated with the substrate solution for PTS, and the $\mathrm{pH}$ was also acceptable for plant culture. This study indicated that alternative substrates could possibly be made from $100 \%$ pine trees. The advantage of PTS is that it can be produced locally in any place that loblolly pine trees can be grown-across much of the United States (Gillman and Watson, 1994) - thus reducing substrate transportation costs associated with peat-lite (PL) substrate. Subsequent work has demonstrated that a $100 \%$ PTS could be manufactured that possesses the same physical properties (percentage of water holding capacity and percentage of air space) as a commercial PL substrate (Saunders et al., 2006). However, Wright and Browder (2005) demonstrated that additional fertilizer applications were required for PTS to maximize plant growth compared with a pine bark substrate. Gruda and Schnitzler (1999) showed that plant growth in $100 \%$ wood substrate was comparable with a peat substrate if the fiber was impregnated with nitrogen $(\mathrm{N})$ during manufacturing or extra $\mathrm{N}$ was added during cultivation. Therefore, this study was undertaken to determine the fertilizer requirements of PTS compared with PL for the growth of chrysanthemum, an important greenhouse pot crop.

\section{Materials and methods}

On 15 Oct. 2005 single rooted cuttings of 'Baton Rouge' chrysanthemum were potted in 8-inch-diameter plastic containers filled with the following substrates: a commercial substrate composed of $45 \%$ peat, $15 \%$ perlite, $15 \%$ vermiculite, and 25\% bark (Fafard, Anderson, SC), supplemented with dolomitic lime at $6 \mathrm{lb} / \mathrm{yard}^{3}$ and calcium sulfate $\left(\mathrm{CaSO}_{4}\right)$ at $1.0 \mathrm{lb} / \mathrm{yard}^{3}$, and PTS. The commercial substrate did not contain a pre-plant fertilizer charge

\begin{tabular}{llll}
\hline $\begin{array}{l}\text { Units } \\
\text { To convert U.S. to SI, } \\
\text { multiply by }\end{array}$ & U.S. unit & SI unit & $\begin{array}{l}\text { To convert SI to U.S., } \\
\text { multiply by }\end{array}$ \\
\hline 2.54 & inch(es) & $\mathrm{cm}$ & 0.3937 \\
25.4 & inch(es) & $\mathrm{mm}$ & 0.0394 \\
645.1600 & inch $^{2}$ & $\mathrm{~mm}^{2}$ & 0.0016 \\
1.1209 & lb/acre & $\mathrm{kg} \cdot h^{-1}$ & 0.8922 \\
4.4482 & $\mathrm{lbf}$ & $\mathrm{N}$ & 0.2248 \\
28.3495 & $\mathrm{Oz}$ & $\mathrm{g}$ & 0.0353 \\
28,350 & $\mathrm{Oz}$ & $\mathrm{mg}$ & $3.5274 \times 10^{-5}$ \\
1 & $\mathrm{ppm}$ & $\mathrm{mg} \cdot \mathrm{L}^{-1}$ & 1 \\
$\left({ }^{\circ} \mathrm{F}-32\right) \div 1.8$ & ${ }^{\circ} \mathrm{F}$ & ${ }^{\circ} \mathrm{C}$ & $\left(1.8 \times{ }^{\circ} \mathrm{C}\right)+32$
\end{tabular}


other than the limestone and $\mathrm{CaSO}_{4}$. The PTS substrate was produced by further grinding coarse $(1.0 \times 1.0 \times$ 0.5 -inch) loblolly pine chips routinely produced for the paper industry with a hammer mill (Meadows Mills, North Wilkesboro, NC) passing through a 3/16-inch screen and incorporated with $1.0 \mathrm{lb} /$ yard $^{3}$ $\mathrm{CaSO}_{4}$. Dolomitic limestone was not added to PTS because PTS pH is normally in the proper range without limestone additions and experiments with marigold 'Inca Gold' seedlings demonstrated that limestone additions reduced growth compared with PTS without limestone (Saunders et al., 2005). Plants were glasshouse grown in Blacksburg, Virginia at temperatures set at $26{ }^{\circ} \mathrm{C}$ day $/ 22{ }^{\circ} \mathrm{C}$ night. A night interruption of continuous light from $100 \mathrm{~W}$ incandescent bulbs supplying $3.35 \mu \mathrm{mol} \cdot \mathrm{m}^{-2} \cdot \mathrm{s}^{-1}$ photosynthetic photon flux from 2200 to 0200 HR was used until the start of short days, on 9 Nov. Plants in each substrate were watered at the same time as needed depending upon weather conditions, and they never showed any symptoms of water stress. Plants were fertilized with each watering by applying, with a cup, $250 \mathrm{~mL}$ of $50,100,200$, or $300 \mathrm{mg} \cdot \mathrm{L}^{-1} \mathrm{~N}$ from Peters $20 \mathrm{~N}-4.4 \mathrm{P}-16.6 \mathrm{~K}$ PeatLite Special (The Scotts Co., Marysville, $\mathrm{OH}$ ) containing $12 \%$ nitrate $\left(\mathrm{NO}_{3}-\mathrm{N}\right)$ and $8 \%$ ammonium $\left(\mathrm{NH}_{4}{ }^{-}\right.$ N). Substrate solution was extracted using the pour-through method (Wright, 1986) on 12 Dec. and was analyzed for $\mathrm{pH}$ and electrical conductivity (EC) using a Hanna HI 9811 instrument. Water-extractable mineral nutrients levels were determined by Quality Analytical Laboratories (Panama City, FL) using a Thermo Jarrell Ash 61E ICP (Franklin, MA) for all nutrients except $\mathrm{NO}_{3}-\mathrm{N}$ and $\mathrm{NH}_{4}-\mathrm{N}$, which were determined colorimetrically with a Quick Chem AE autoanalyzer (Lachat, Loveland, CO). On 22 Dec., a growth index [(height + widest width + perpendicular width $\div 3$ ] of each plant was taken and stems were severed at the substrate surface, dried, and weighed. Another experiment was conducted in Spring 2006 when, on 12 Apr., rooted cuttings of 'Baton Rouge' chrysanthemums were potted in the above substrates in 6-inch-diameter pots. A higher rate of fertilizer was used in 2006 because growth in PTS

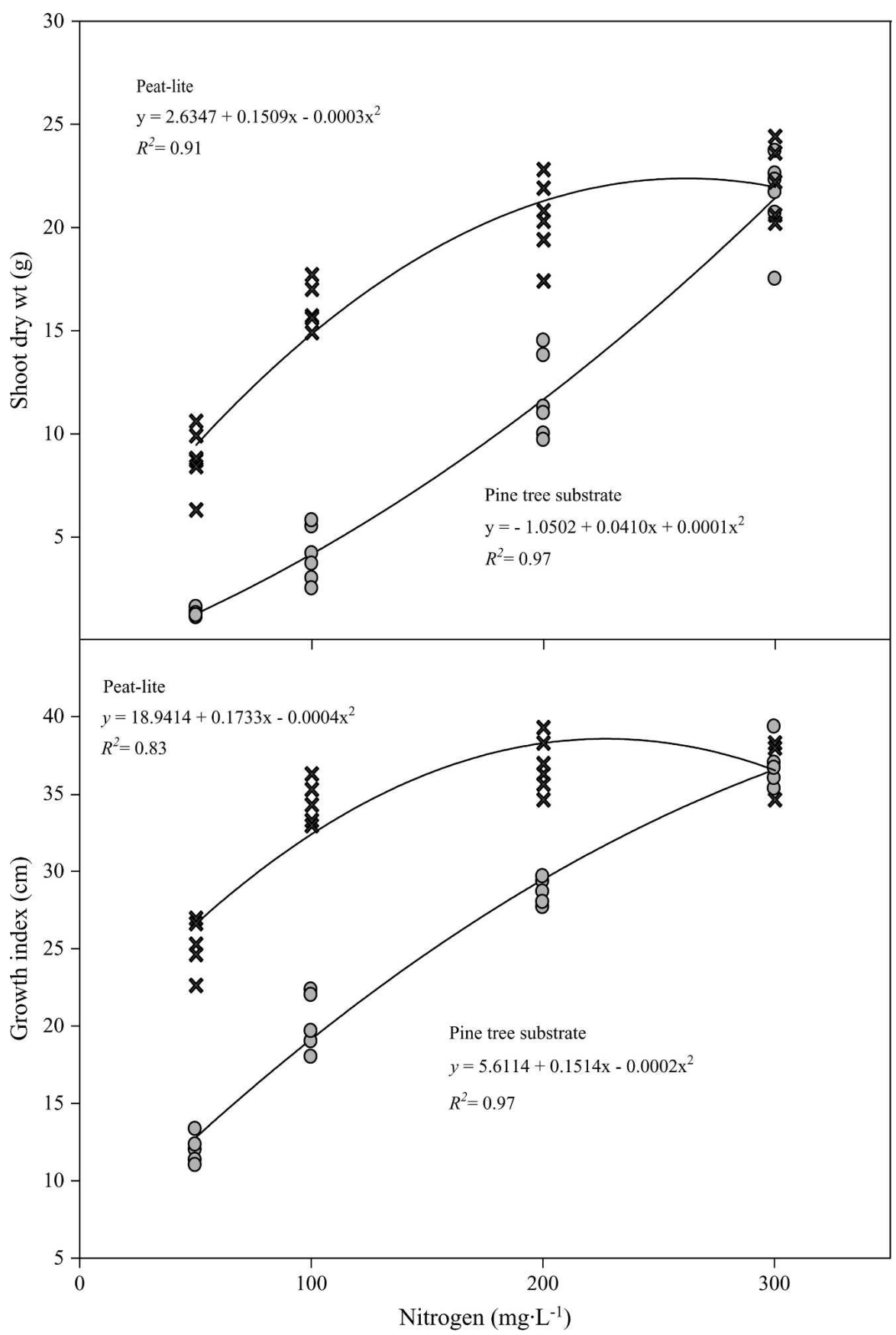

Fig. 1. Shoot dry weight and growth index [ (height + widest width + perpendicular width)/3] of chrysanthemum 'Baton Rouge' grown from 15 Oct. 2005 to 22 Dec. 2005 in peat-lite $(X)$ or pine tree substrate $(O)$ with four different rates of a $20 \mathrm{~N}-4.4 \mathrm{P}-$ $16.6 \mathrm{~K}$ soluble fertilizer containing $12 \% \mathrm{NO}_{3}-\mathrm{N}$ (nitrate nitrogen) and $8 \% \mathrm{NH}_{4}-\mathrm{N}$ $($ ammonium $\mathrm{N}) .(\mathrm{N}=5) ; 1 \mathrm{mg} \cdot \mathrm{L}^{-1}=1 \mathrm{ppm} ; 1 \mathrm{~g}=0.0353 \mathrm{oz} \cdot ; 1 \mathrm{~cm}=2.45$ inches.

was not optimal at $300 \mathrm{mg} \cdot \mathrm{L}^{-1} \mathrm{~N}$ in 2005. There were four rates of the above fertilizer $(100,200,300$, and $400 \mathrm{mg} \cdot \mathrm{L}^{-1} \mathrm{~N}$ ) applied with each irrigation. Substrate solution was extracted using the PT method (Wright, 1986) on 10 May and was analyzed for $\mathrm{pH}$ and $\mathrm{EC}$ as above and $\mathrm{NO}_{3}-\mathrm{N}$ with an Orion ion selective electrode (Thermo Electron, Beverly, $\mathrm{MA})$. The phosphorus (P) and potassium $(\mathrm{K})$ levels were determined with a Spectro Ciros Vision ICP (Spectro Analytical Instrument, Mahwah, NJ). On 1 June, growth measurements were taken as above. Physical properties of each substrate were determined pre-plant according to Tyler et al. (1993) on four replicate samples of each substrate using the North Carolina State University porometer method. Volumetric water 
retention at $1500 \mathrm{kPa}$, was collected according to Klute (1986) and Milks et al. (1989). Container capacity was calculated according to methods developed by Bilderback and Fonteno (1987) and modified by Milks et al. (1989). Cation exchange capacity (CEC) was determined by A \& L Eastern Agricultural Laboratories (Richmond, VA) according to the AOAC International Official Method (973.09, CEC for peat; Thrope, 1973). Both studies were arranged in a completely randomized design with five replications. Data were subjected to analysis of variance and regression analysis $(P<0.05)$ using SigmaPlot (version 9.01; SPSS, Inc., Chicago) with the exception that comparison between PL and PTS was subjected to a least significant difference (release 9.1; SAS Institute, Cary, NC).

\section{Results and discussion}

In 2005, the maximum shoot dry weight and growth index for chrysanthemums occurred at about $200 \mathrm{mg} \cdot \mathrm{L}^{-1} \mathrm{~N}$ with $\mathrm{PL}$ with no increase from 200 to $300 \mathrm{mg} \cdot \mathrm{L}^{-1} \mathrm{~N}$ (Fig. 1). Plant growth in PTS continued to increase up to $300 \mathrm{mg} \cdot \mathrm{L}^{-1} \mathrm{~N}$ where it was similar to PL plants grown at $200 \mathrm{mg} \cdot \mathrm{L}^{-1} \mathrm{~N}$. Whether growth would be higher at higher $\mathrm{N}$ rates for PTS is not known, but line slope indicates that further growth increases could occur if fertilizer rates were increased. Growth response was similar in the 2006 experiment except that maximum growth for PL was at $300 \mathrm{mg} \cdot \mathrm{L}^{-1} \mathrm{~N}$ and at $400 \mathrm{mg} \cdot \mathrm{L}^{-1} \mathrm{~N}$ for PTS. Growth response to fertilizer rate in PTS was linear up to 400 $\mathrm{mg} \cdot \mathrm{L}^{-1} \mathrm{~N}$ (Fig. 2) in 2006 compared with $300 \mathrm{mg} \cdot \mathrm{L}^{-1} \mathrm{~N}$ for 2005 . Further growth increase is therefore possible at higher fertility rates for PTS. For both experiments, on the basis of $\mathrm{N}$, PTS required about $100 \mathrm{mg} \cdot \mathrm{L}^{-1} \mathrm{~N}$ more fertilizer than PL to obtain comparable growth. Supportive of our work, Still et al. (1972) reported chrysanthemums grown in white oak (Quercus alba) sawdust and fertilized at $400 \mathrm{mg} \cdot \mathrm{L}^{-1} \mathrm{~N}$ had growth comparable with a peat-based substrate, and Gruda and Schnitzler (1999) showed that extra $\mathrm{N}$ during the cultivation of tomato (Solanum lycopersicum) seedlings in a wood fiber substrate resulted in growth equal to plants grown in peat.

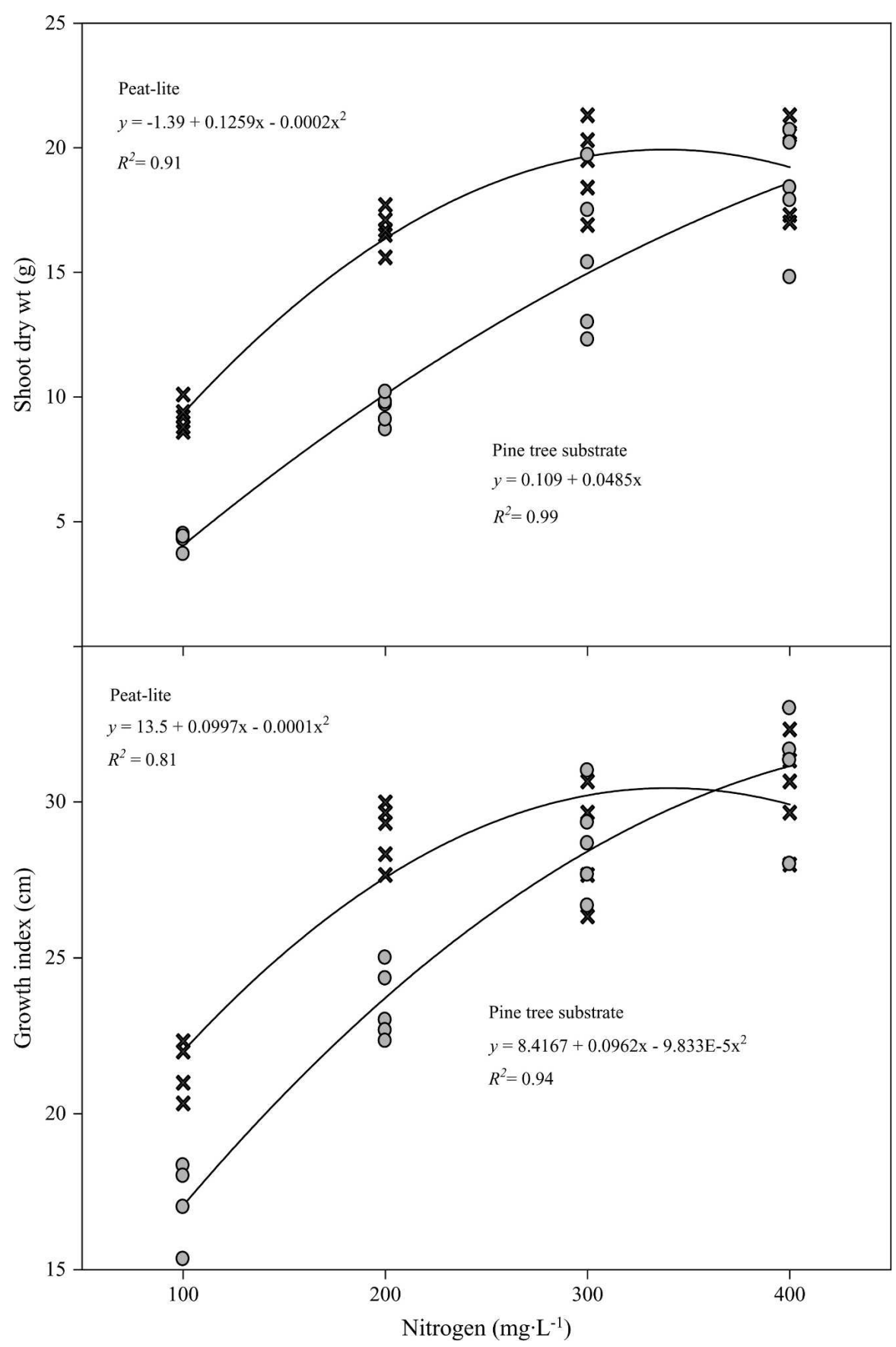

Fig. 2. Shoot dry weight and growth index [ (height + widest width + perpendicular width)/3] of chrysanthemum 'Baton Rouge' grown from 12 April 2006 to 1 June 2006 in peat-lite $(X)$ or pine tree substrate $(O)$ with four different rates of a $20 \mathrm{~N}-$ $4.4 \mathrm{P}-16.6 \mathrm{~K}$ soluble fertilizer containing $12 \% \mathrm{NO}_{3}-\mathrm{N}$ (nitrate nitrogen) and $8 \%$ $\mathrm{NH}_{4}-\mathrm{N}$ (ammonium nitrogen). $(\mathrm{N}=5) ; 1 \mathrm{mg} \cdot \mathrm{L}^{-1}=1 \mathrm{ppm} ; 1 \mathrm{~g}=0.0353 \mathrm{oz}$; $1 \mathrm{~cm}=$ 2.45 inches.

In 2005, substrate $\mathrm{pH}$ was higher for PTS than for PL (Table 1). In 2006, $\mathrm{pH}$ was higher for PL than PTS (Table 2). Why pH differences between PTS and PL were not consistent between years is not understood. Substrate $\mathrm{pH}$ followed the normal response of decreasing with increasing fertilizer rate for both substrates, with the exception of PTS in 2005 when it remained unchanged (Table 1). Overall, though, $\mathrm{pH}$ for both substrates in both years was in an acceptable range for chrysanthemum growth ( $\mathrm{pH}$ 5.7-6.2) with the possible exception of the $300 \mathrm{mg} \cdot \mathrm{L}^{-1} \mathrm{~N}$ PL treatment in 2005 and the 100 to $300 \mathrm{mg} \cdot \mathrm{L}^{-1} \mathrm{~N}$ PL treatment in 2006 
Table 1. Chrysanthemum substrate solution $\mathrm{pH}$, electrical conductivity (EC), and nutrient concentrations sampled on 12 Dec. 2005 with pour-through method for peat-lite (PL) or pine tree substrate (PTS) fertilized with four different rates of $20 \mathrm{~N}-4.4 \mathrm{P}-16.6 \mathrm{~K}$-soluble fertilizer containing $12 \%$ nitrate nitrogen $\left(\mathrm{NO}_{3}-\mathrm{N}\right)$ and $8 \%$ ammonium nitrogen $(\mathrm{NH} 4-\mathrm{N})$.

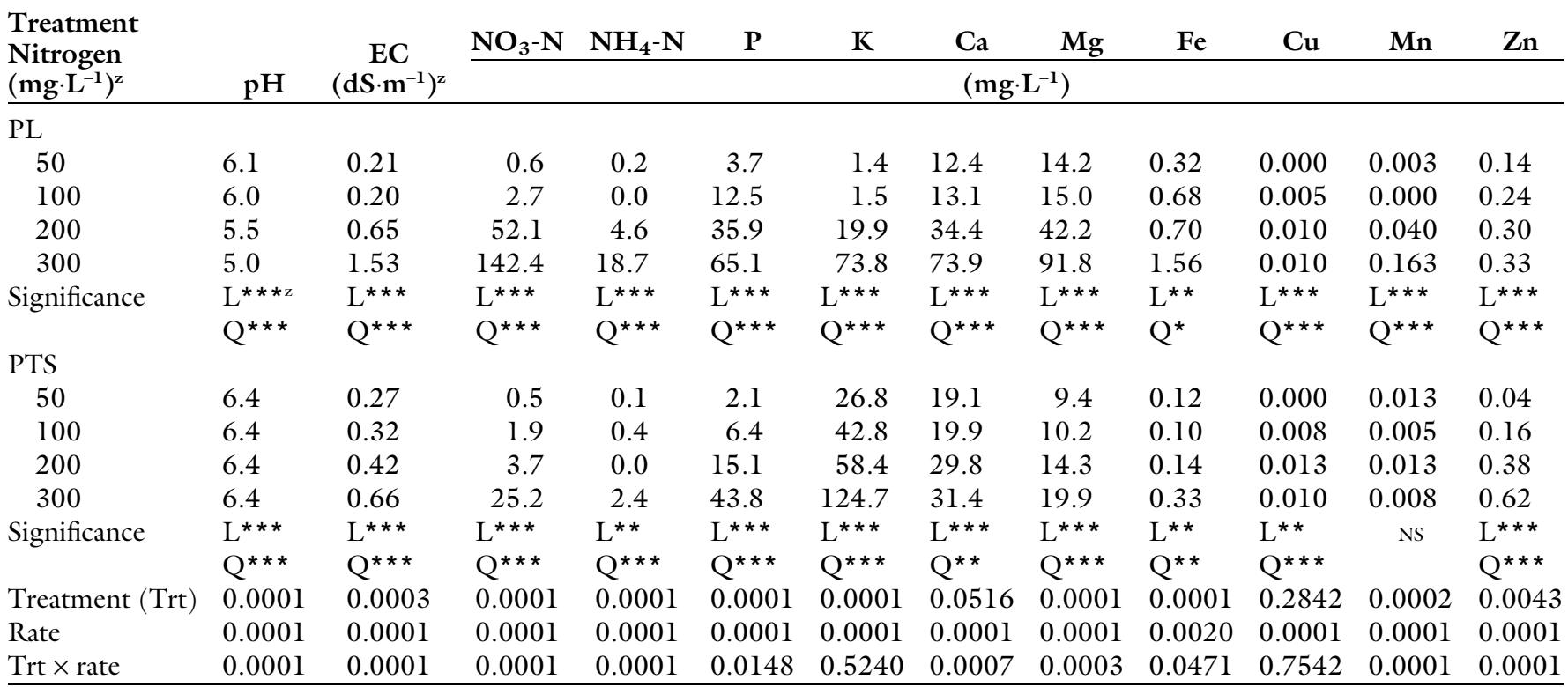

${ }^{2} 1 \mathrm{mg} \cdot \mathrm{L}^{-1}=1 \mathrm{ppm}, \mathrm{l} \mathrm{dS} \cdot \mathrm{m}^{-1}=1 \mathrm{mmho} / \mathrm{cm}$.

Ns, ${ }^{* * * * * * *}$ Nonsignificant or significant at $P=0.05,0.01$, or 0.001 , respectively.

$\mathrm{L}$, linear; $\mathrm{Q}$, quadratic response for concentration at ${ }^{*},{ }^{*}$, or ${ }^{* * *}$

(Nelson, 2003). For both years, EC and nutrient levels were generally higher in PL compared with PTS with the exception of $\mathrm{K}$, which was higher in PTS in 2006 at all rates except 400 $\mathrm{mg} \cdot \mathrm{L}^{-1} \mathrm{~N}$. Even though there were other exceptions, the main point of the substrate water-extractable nutrient content data are that nutrient levels are generally lower in PTS than in PL and thus higher levels of fertilizer are required for plant growth in

Table 2. Chrysanthemum substrate solution $\mathrm{pH}, \mathrm{EC}$, and nutrient concentrations sampled on 10 May 2006 with pour through method for peat-lite (PL) or pine tree substrate (PTS) fertilized with four different rates of a $20 \mathrm{~N}-4.4 \mathrm{P}-16.6 \mathrm{~K}$-soluble fertilizer containing $12 \%$ nitrate nitrogen $\left(\mathrm{NO}_{3}-\mathrm{N}\right)$ and $8 \%$ ammonium nitrogen $\left(\mathrm{NH}_{4}-\mathrm{N}\right)$.

\begin{tabular}{|c|c|c|c|c|c|}
\hline $\begin{array}{l}\text { Treatment } \\
\text { Nitrogen } \\
\left(\mathrm{mg} \cdot \mathrm{L}^{-1}\right)^{\mathrm{z}} \\
\end{array}$ & $\mathrm{pH}$ & $\begin{array}{c}\text { EC } \\
\left(\mathrm{dS} \cdot \mathrm{m}^{-1}\right)^{\mathrm{z}}\end{array}$ & $\mathrm{NO}_{3}-\mathrm{N}$ & $\begin{array}{r}\text { Phosphorus } \\
\left(\mathrm{mg} \cdot \mathrm{L}^{-1}\right)\end{array}$ & Potassium \\
\hline \multicolumn{6}{|l|}{ PL } \\
\hline 100 & 7.1 & 0.93 & 4.8 & 4.4 & 8.7 \\
\hline 200 & 6.9 & 1.58 & 17.0 & 22.9 & 13.7 \\
\hline 300 & 6.6 & 2.82 & 218.5 & 58.2 & 85.7 \\
\hline 400 & 6.1 & 4.41 & 413.8 & 63.7 & 190.8 \\
\hline \multirow[t]{2}{*}{ Significance ${ }^{y}$} & $\mathrm{~L}^{* * *}$ & $\mathrm{~L}^{* * *}$ & $\mathrm{~L}^{* * *}$ & $\mathrm{~L}^{* * *}$ & $\mathrm{~L}^{* * *}$ \\
\hline & $\mathrm{Q}^{* * *}$ & $\mathrm{Q}^{* * *}$ & $\mathrm{Q}^{\star \star *}$ & $\mathrm{Q}^{* * *}$ & $\mathrm{Q}^{* * *}$ \\
\hline \multicolumn{6}{|l|}{ PTS } \\
\hline 100 & 6.3 & 0.47 & 2.3 & 4.0 & 22.0 \\
\hline 200 & 6.3 & 0.53 & 15.2 & 29.2 & 58.0 \\
\hline 300 & 5.9 & 1.14 & 80.5 & 73.3 & 116.6 \\
\hline 400 & 5.6 & 1.56 & 150.3 & 68.4 & 123.9 \\
\hline \multirow[t]{2}{*}{ Significance } & $\mathrm{L}^{\star * *}$ & $\mathrm{~L}^{* * *}$ & $\mathrm{~L}^{* * *}$ & $\mathrm{~L}^{* * *}$ & $\mathrm{~L}^{\star * *}$ \\
\hline & $Q^{* * *}$ & $Q^{* * *}$ & $Q^{* * *}$ & $Q^{* \star *}$ & $Q^{* * *}$ \\
\hline Treatment (Trt) & 0.0001 & 0.0001 & 0.0001 & 0.0655 & 0.5254 \\
\hline Rate & 0.0001 & 0.0001 & 0.0001 & 0.0001 & 0.0001 \\
\hline Trt $\times$ rate & 0.6420 & 0.0001 & 0.0001 & 0.4313 & 0.0004 \\
\hline
\end{tabular}

${ }^{\mathrm{z}} 1 \mathrm{mg} \cdot \mathrm{L}^{-1}=1 \mathrm{ppm}, \mathrm{l} \mathrm{dS} \cdot \mathrm{m}^{-1}=1 \mathrm{mmho} / \mathrm{cm}$.

${ }^{y}$ Linear $(\mathrm{L})$ or quadratic $(\mathrm{Q})$ response for concentration at ${ }^{*},{ }^{*}$, or $* * *$, where $P=0.05,0.01$, or 0.001 , respectively.

PTS to obtain comparable growth. Overall, substrate EC was about 1.6 and 3.9 times higher for PL compared with PTS for 2005 and 2006, respectively. Lower substrate solution EC for PTS compared with pine bark has been reported before (Wright and Browder, 2005) and has been demonstrated in a number of other unpublished studies by these authors. One reason for the lower substrate nutrient levels for PTS may be that PTS is more porous (percentage of air space) than PL (Table 3 ) and has a saturated hydraulic conductivity determined according to Klute and Dirksen (1986) of $1.1 \mathrm{~cm} \cdot \mathrm{s}^{-1} \mathrm{com}-$ pared with only $0.42 \mathrm{~cm} \cdot \mathrm{s}^{-1}$ for PL (R.D. Wright and B.E. Jackson, unpublished data). The CEC for PTS is about five times lower than PL (Table $3)$. In total, these factors would likely contribute to more nutrient leaching with PTS during irrigation and would lead to environmental concerns relating to nutrient runoff from production facilities. Growing chrysanthemums in a more finely ground substrate could reduce porosity, increase water-holding capacity, and reduce nutrient leaching. A second reason for lower substrate nutrient levels in PTS compared with PL may relate to increased microbial $\mathrm{N}$ immobilization (Tisdale et al., 1993) for PTS, which 
Table 3. Physical properties of peat-lite (PL) and pine tree substrate (PTS) substrates used in this study of chrysanthemum growth.

\begin{tabular}{|c|c|c|c|c|c|c|c|}
\hline \multirow[b]{2}{*}{$\underline{\text { Substrates }}$} & $\begin{array}{c}\begin{array}{c}\text { Total } \\
\text { porosity }^{z}\end{array} \\
\end{array}$ & $\begin{array}{c}\text { Air } \\
\text { space }^{y}\end{array}$ & $\begin{array}{l}\text { Container } \\
\text { capacity }^{\mathrm{x}}\end{array}$ & $\begin{array}{c}\text { Unavailable } \\
\text { water }^{\text {w }}\end{array}$ & $\begin{array}{c}\text { Available } \\
\text { water }^{v}\end{array}$ & \multirow{2}{*}{$\begin{array}{c}\text { Bulk } \\
\text { density } \\
\left(\mathrm{g} \cdot \mathrm{cm}^{-3}\right)^{\mathbf{u}}\end{array}$} & \multirow{2}{*}{$\begin{array}{c}\text { Cation } \\
\text { exchange } \\
\text { capacity } \\
\left(\mathrm{cmol} \cdot \mathrm{L}^{-1}\right)\end{array}$} \\
\hline & \multicolumn{5}{|c|}{ (\% volume) } & & \\
\hline PTS & 79 & 31 & 48 & 22 & 26 & 0.15 & 2.1 \\
\hline $\mathrm{LSD}_{0.05^{\mathrm{t}}}$ & 1.68 & 3.44 & 2.50 & 1.89 & 3.12 & 0.01 & 0.36 \\
\hline
\end{tabular}

${ }^{\mathrm{z}}$ Total porosity is equal to container capacity + air space.

yAir space is the volume of water drained from the sample $\div$ volume of the sample.

${ }^{x}$ Container capacity is (wet weight - oven dry weight) $\div$ volume.

wBased on percent volume of a $3-\times 1$-inch $(7.6 \times 2.5 \mathrm{~cm})$ core at $1500 \mathrm{kPa}(217.6 \mathrm{psi})$.

${ }^{\vee}$ Container capacity - unavailable water.

${ }^{\mathrm{u}} \mathrm{l} \mathrm{g} \cdot \mathrm{cm}^{-3}=0.5780 \mathrm{oz} / \mathrm{inch}^{3}$.

${ }^{\mathrm{t}}$ Means separation between PL and PTS by least significant difference at $P=0.05$.

has a high carbon:nitrogen ratio compared to PL. Unpublished results (B.E. Jackson) have shown substrate respiration rates for PTS to be five times that of $\mathrm{PL}$, pointing to an increased microbial activity for PTS and higher immobilization of $\mathrm{N}$.

Differences in various substrate nutrient levels shown in this study between PTS and PL should not cause concern in terms of the suitability of PTS as a container substrate. There were no visual symptoms related to nutrient disorders with the exception of those normally associated with insufficient nutrients at the lower fertilizer rates. The reasons for the higher fertilizer requirements for PTS compared with PL need to be investigated with the intention of possibly altering PTS to overcome these concerns. Although there is an added production cost associated with extra fertilizer, there are cost advantages with PTS compared with peatmoss substrates. For example, PTS can be ground to a particle size that provides acceptable water and aeration levels in the substrate without the added expense of incorporating perlite or vermiculite, which are normally added to peatmoss. In addition, PTS can be produced locally where loblolly pine trees can be grown, reducing the transportation costs associated with peatmoss.

\section{Literature cited}

Bilderback, T.E. and W.C. Fonteno. 1987. Effects of container geometry and media physical properties on air and water volumes in containers. J. Environ. Hort. 5:180-182.

Evans, M.R. and R.L. Harkess. 1997. Growth of Pelargonium $\times$ hortorum and
Euphorbia pulcherrima in rubber-containing substrates. HortScience 32:874-877.

Evans, M.R., S. Konduru, and R.H. Stamps. 1996. Source variation in physical and chemical properties of coconut coir dust. HortScience 31:965-967.

Gillman, E.F. and D.G. Watson. 1994. Pinus taeda, loblolly pine. U.S. Dept. Agr., Forest Service, Fact Sheet ST-478.

Gruda, N. and W.H. Schnitzler. 1999. Influence of wood fiber substrates and N application rates on the growth of tomato transplants. Adv. Hort. Sci. 13:20-24.

Hidalgo, P.R. and R.L. Harkess. 2002. Earthworm castings as a substrate for poinsettia production. HortScience 37:304-308.

Klute, A. 1986. Water retention: Laboratory methods, p. 635-662. In: A. Klute (ed.). Methods of soil analysis. Part 1. Physical mineralogical methods. Monograph 9, 2nd ed. Amer. Soc. Agron., Soil Sci. Soc. Amer., Madison, WI.

Klute, A. and C. Dirksen. 1986. Hydraulic conductivity and diffusivity: Laboratory methods, p. 687-734. In: A. Klute (ed.). Methods of soil analysis, Part 1. Physical mineralogical methods. Monograph 9, 2nd ed. Amer. Soc. Agron., Soil Sci.Soc. Amer., Madison, WI.

Maas, E.F. and R.M. Adamson. 1982. Artificial media in horticulture: Their formulation and fertilization. Agriculture Canada Publ. 1726/E.

Milks, R.R., W.C. Fonteno, and R.A. Larson. 1989. Hydrology of horticultural substrates: II. Predicting physical properties of media in containers. J. Amer. Soc. Hort. Sci. 114:53-56.

Nelson, P.V. 2003. Greenhouse operations and management. 6th ed. Prentice Hall, Upper Saddle River, NJ.

Saunders, T.N., B. Jackson, R. Wright, and J. Browder. 2006. Particle size of a pine chips substrate affects plant growth. Proc. Southern Nursery Assn. Res. Conf. 51:45-47.

Saunders, T.N., R.D. Wright, and J.F. Browder. 2005. Chipped pine logs: A potential substrate for nursery and greenhouse crops. Proc. Southern Nursery Assn. Res. Conf. 50:112-114.

Scott, E.G. and B.C. Bearce. 1972. A hardwood-bark-sawdust compost for greenhouse pot flower production. Forest Products J. 22:36-39.

Still, S., J.B. Gartner, and T.D. Hughes. 1972. Effect of sawdust age and nitrogen application on chrysanthemums grown in white oak sawdust media. Forest Products J. 22:111-114.

Thrope, V.A. 1973. Collaborative study of the cation exchange capacity of peat materials. J. AOAC 56:154-156.

Tisdale, S.L., W.L. Nelson, J.D. Beaton, and J.L. Havlin. 1993. Soil fertility and fertilizers. 5th ed. Macmillan, New York.

Tyler, H.H., S.L. Warren, T.E. Bilderback, and W.C. Fonteno. 1993. Composted turkey litter: I. Effect of chemical and physical properties of a pine bark substrate. J. Environ. Hort. 11:131-136.

Wang, Y. and T.M. Blessington. 1990. Growth of interior performance of poinsettia in media containing composted cotton burrs. HortScience 25:407-408.

Worrall, R.J. 1981. Comparison of composted hardwood and peat-based media for the production of seedlings, foliage and flowering plants. Scientia Hort. 15:311-319.

Wright, R.D. 1986. The pour through nutrient extraction procedure. HortScience 21:227-229.

Wright, R.D. and J.F. Browder. 2005. Chipped pine logs: A potential substrate for nursery and greenhouse crops. HortScience 40:1513-1515. 